\title{
2020 Update on 2003 Article "Human Histology and Persistence of Various Injectable Filler Substances for Soft Tissue Augmentation"
}

\author{
Gottfried Lemperle ${ }^{1,2}$
}

Published online: 5 August 2020

(C) Springer Science+Business Media, LLC, part of Springer Nature and International Society of Aesthetic Plastic Surgery 2020

The reason for these simple tests was the lack of knowledge on the effects and reactions of surging dermal fillers in 2003. How can we as physicians inject any dermal filler not knowing what histologic reactions it causes in the dermis and beneath? What is the mechanism of its absorption, and how long does it last? Does a filler remain where it is injected, or does it dissipate in the surrounding tissue like some fluid fillers? What kind of cells are attacking or removing the different fillers, and which fillers may induce an excessive foreign body response and how can it be treated? How effective are antidots like hyaluronidase or corticosteroids in the treatment of granulomas [1], or as some call a granuloma today: a 'late-onset inflammatory adverse reaction'?

During the past two decades, we have greatly expanded our understanding and knowledge of various different fillers that are now ranging from 6 months to 5 years in efficacy with our increased understanding of each filler's unique histologic response over time.

Since our original publication in 2003 [2], I have continuously injected more than 100 blebs of different fillers beneath the dermis of my left forearm (Fig. 1). Human skin reacts differently compared to the skin of pigs, rats, or mice.

For the past 35 years, tissue biocompatibility and longevity of various available fillers became the major interest of dermal filler research (Fig. 2). The finding of the most suitable carrier for micro-particulate fillers, whether

Gottfried Lemperle

Lemperle8@aol.com

1 Division of Plastic Surgery, University of California, San Diego, 200 West Arbor Drive, San Diego, CA 92103-8890, USA

2 Wolfsgangstr. 64, 60322 Frankfurt am Main, Germany bovine collagen, hyaluronic acid, carboxymethyl-cellulose, or even alginate, is an important issue in developing new fillers in the future.

Human tissues remain ideal test sites for optimal concentrations of microparticles, which shall smoothly pass long catheters, which have certain diameters to prevent entering small veins, and are stimulating enough connective tissue to form "living implants" in the skin or "vascularized bulking agents".

Interestingly, of the 10 tested dermal fillers commonly used in Europe back in 2003, half of them soon disappeared from the market: Zyderm ${ }^{\circledR}$ and Zyplast ${ }^{\circledR}$ have been displaced by Restylane ${ }^{\circledR}$ and Juvederm ${ }^{\circledR}$, and fluid silicone 350, Reviderm ${ }^{\circledR}$, Dermalive ${ }^{\circledR}$, and Evolution ${ }^{\circledR}$, were causing an unacceptable rate of foreign body granulomas (Fig. 3) [1].

In 2020, Restylane remains the \#1 filler globally among the approximately 150 hyaluronic acid (HA) fillers available, which slightly differ in cross-linking, and concentration. HA fillers today account for about $80 \%$ of the global filler market. On the other side of the spectrum, the permanent PMMA-collagen filler Artecoll ${ }^{\circledR}$ has been widely and safely used in China since 2002, and ArteFill ${ }^{\circledR}$ (now Bellafill ${ }^{\circledR}$ ) has been used successfully in the U.S., and some other countries since its FDA approval in 2006 [3].

Two PMMA-microsphere-based fillers using carboxymethyl-cellulose as carrier (Linnea safe ${ }^{\circledR}$ and Biosimetric $\left.{ }^{\circledR}\right)$ are leading in Brazil due to their much cheaper price, PLA-based Newfill ${ }^{\circledR}$ changed its name to Sculptra ${ }^{\circledR}$, which experienced its greatest success during times of more prevalent HIV-facial-dystrophy, Aquamid ${ }^{\circledR}$ claims biofilm-infection for its increasing rate of foreign body granulomas, and Radiesse ${ }^{\circledR}$, formerly called Radiance ${ }^{\circledR}$, 


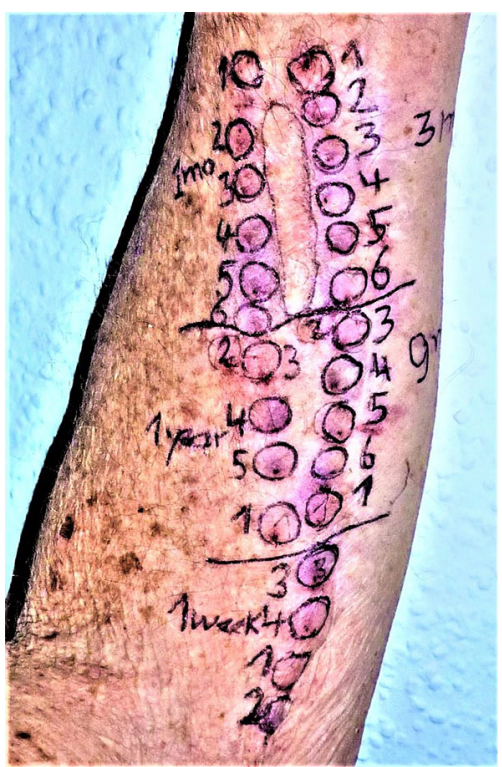

Fig. 1 Five-times six injections of different carriers and concentrations of a new bulking agent to find out the optimal stimulation of connective tissue. All areas are excised after 1 week, and 1, 3, 9, and 12 months. Locators for excision are post-injection photography along with an implanted strip of medical silicone

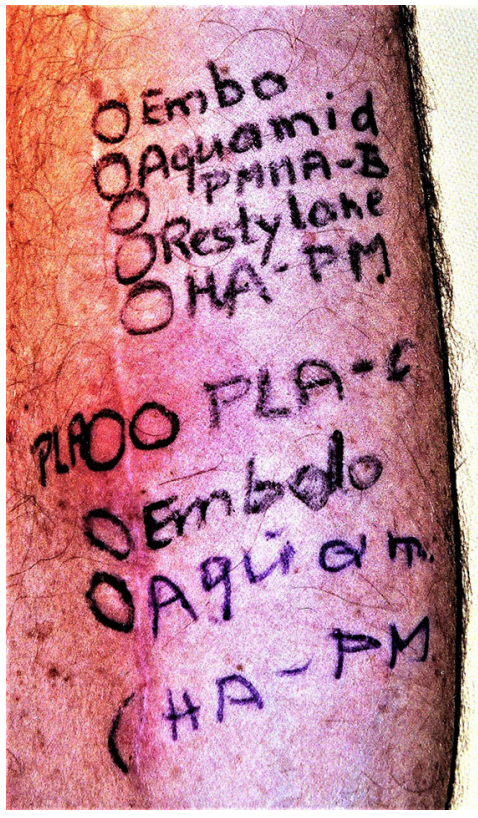

Fig. 2 Injected different dermal fillers in 2003, when their respective histological reactions were still unknown

remains a reliable longer-lasting product showing very low granuloma rates [1].

Aside from some slightly different hyaluronic acid fillers like Belotero ${ }^{\circledR}$ and Teosyal ${ }^{\circledR}$, no truly novel dermal filler technology has been introduced in the aesthetics markets within the last few years.

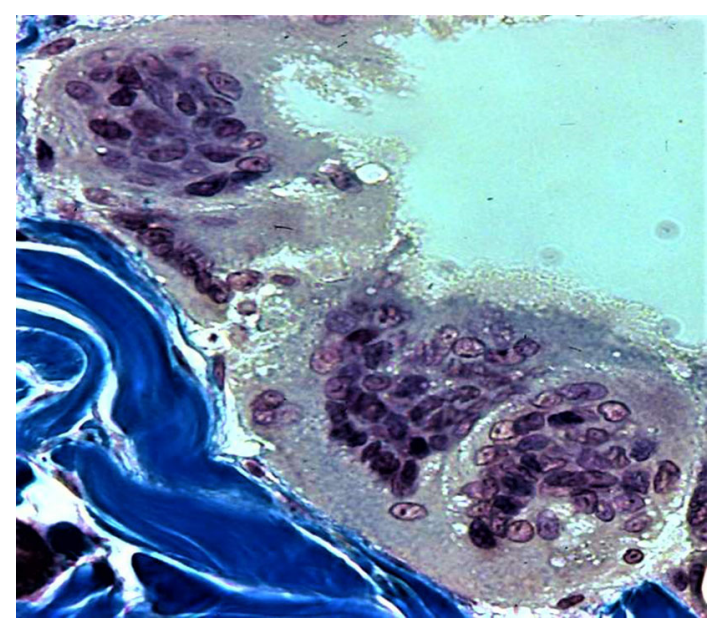

Fig. 3 Avian hyaluronic acid (Reviderm ${ }^{\mathrm{TM}}$ ) is slowly removed by pinocytosis of foreign body giant cells. Therefore, HA from cockscombs is unsuitable as a dermal filler

The latest filler Ellanse' ${ }^{\circledR}$ is made of polycaprolactone microspheres, a bio-resorbable soft polymer, suspended in carboxymethyl-cellulose gel. It claims to last up to 4 years and to stimulate collagen production ("neocollagenesis"); yet histologically, new tissue formation shows the common foreign body reaction against all particulate fillers that disappears along with the absorption of its microspheres.

Convincing evidence of different longevities can only be provided by sequential histological pictures which demonstrate residue of a certain filler at a certain time [2]. We will have to be patient and see what kind of new dermal filler technologies will enter the aesthetics market in the future. At present, I am testing tissue reactions of larger microspheres as 'bulking agents' in the treatment of

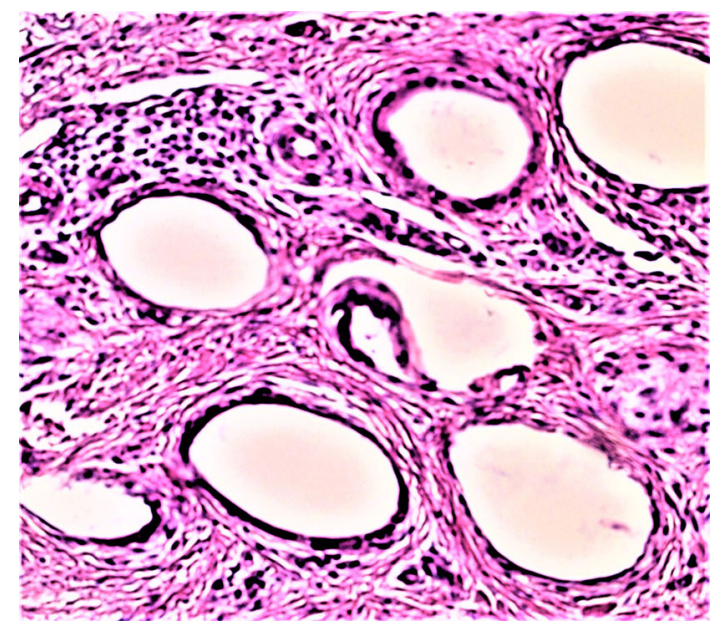

Fig. 4 PMMA-microspheres of $135 \mu \mathrm{m}$ in diameter at 4 weeks: a high number of macrophages of $10 \mu \mathrm{m}$ in size attach their raw surface, "encapsulate" and fix them. If the surface is too smooth (like in Durasphere ${ }^{\circledR}$ or Embosphere $\left.{ }^{\circledR}\right)$ macrophages will not attach and fix the spheres but let them sink according to gravity 
gastric reflux disease or urinary incontinence (Figs. 1 and 4) $[4,5]$.

In conclusion In order to generate objective information about human host tissue reaction around different dermal fillers, the skin of a volunteer forearm is a free of charge and faster testing site compared to animal skin, and most importantly it does not require approval by Internal Review Boards and ethics commissions. There are no ethical or legal barriers to harmless self-experimentation [6], and the filler industry as a whole will benefit from continuing human histology at different time points.

\section{References}

1. Lemperle G, Gauthier-Hazan N, Wolters M, Eisemann-Klein M, Zimmermann U, Duffy DM (2009) Foreign body granulomas after all injectable dermal fillers. Part 1: Possible causes. Plast Reconstr Surg 123:1842-1863
2. Lemperle G, Morhenn VB, Charrier U (2003) Human histology and persistence of various injectable filler substances for soft tissue augmentation. Aesth Plast Surg 27:354-366

3. Lemperle G, Neugebauer P, Kernke R, Lerche K-H, Lemperle SM (2017) Microspheres for cosmetic and medical injections must be free of phagocytosable microparticles under 20 microns. Biomed J Sci Tech Res 1(6):1-5

4. Kamler J, Lemperle G, Lemperle SM, Lehman GA (2010) Endoscopic lower esophageal sphincter bulking for the treatment of GERD: safety evaluation of injectable polymethylmethacrylate microspheres in miniature swine. Gastrointest Endosc 72:337-342

5. Lemperle G, Lappin PB, Stone C, Lemperle SM (2011) Urethral bulking with polymethylmethacrylate microspheres for stress urinary incontinence: tissue persistence and safety studies in miniswine. Urology 77:1005.e1-1005.e7

6. Hanley BP, Bains W, Church G (2019) Review of scientific selfexperimentation: ethics history, regulation, scenarios, and views among Ethics Committees and prominent scientists. Rejuvenation Res 22(2):31-42

Publisher's Note Springer Nature remains neutral with regard to jurisdictional claims in published maps and institutional affiliations. 